\title{
Article \\ Effect of Land Property Rights on Forest Resources in Southern China
}

\author{
Yang Yang ${ }^{1}$, Hua $\mathrm{Li}^{2}$, Long Cheng ${ }^{1}$ and Youliang Ning ${ }^{3, *}$ \\ 1 School of Economics and Management, Xi'an University of Posts \& Telecommunications, Xi'an 710061, China; \\ yangyang@xupt.edu.cn (Y.Y.); chenglong@xupt.edu.cn (L.C.) \\ 2 College of Economics and Management, Northwest Agriculture \& Forestry University, \\ Yangling 712100, China; lihua7485@nwafu.edu.cn \\ 3 Research Institute of Forestry Policy and Information, Chinese Academy of Forestry, Beijing 100091, China \\ * Correspondence: ningyouliang@caf.ac.cn
}

Citation: Yang, Y.; Li, H.; Cheng, L.; Ning, Y. Effect of Land Property Rights on Forest Resources in Southern China. Land 2021, 10, 392. https://doi.org/10.3390/land10040392

Academic Editors: Assem Abu Hatab Nasem Baderldin and Zhen Liu

Received: 6 March 2021

Accepted: 7 April 2021

Published: 9 April 2021

Publisher's Note: MDPI stays neutral with regard to jurisdictional claims in published maps and institutional affiliations.

Copyright: (c) 2021 by the authors. Licensee MDPI, Basel, Switzerland. This article is an open access article distributed under the terms and conditions of the Creative Commons Attribution (CC BY) license (https:/ / creativecommons.org/licenses/by/ $4.0 /)$.
Abstract: The land tenure reform is important for forest resource management worldwide. Since China initiated a new round of collective forestland tenure reform (CFTR) in 2003, improving forest output by clarifying property rights plays a crucial role in realizing sustainable forest resource management. Using survey data of 312 bamboo plantation households from Southern China, this paper empirically examines the impact path of land property rights on forest resources. The estimation results show that both the forestland use right and disposal right are able to significantly improve the forest output by encouraging households to invest and optimizing the allocation of forestry labor. Particularly, the results reveal that the use right has a positive impact on forest output through forestland investment. With regard to the disposal right, we find that it has a positive effect on forest output through forestland investment, but it has a negative impact on forest output through the forestry labor allocation. The findings of this study suggest that to promote the growth of forest resources, the government should endow households with a more complete set of rights, and further strengthen their understanding of property rights. In addition, our findings enhance the understanding of the collective forestland tenure reform in China; they also have implications for the decentralized management of forestry elsewhere in the world.

Keywords: land property right; forest resources; forest output; forestland investment; forestry labor allocation

\section{Introduction}

As one of the most important resources on Earth, forest resources provide various goods for human beings, play an essential ecosystem service function in protecting biodiversity, regulating climate and conserving water resources [1-3]. Property rights are considered the most important policy topic to the development of forest resources [4-6]. Many countries have implemented forestland tenure reforms through the decentralization and devolution to confirm or transfer forestland to local communities [7,8]. For example, joint forest management in India, community forestry in Nepal, public participation in the United States and First Nations rights in Canada [9-11]. Forestry decentralized management has become increasingly important in the world.

In China, $61.3 \%$ of the National Forest Area is collective forest, which plays an essential role in national forestry development [12]. According to statistics, the productivity level of the collective forestland only takes $49 \%$ of the state-owned forestland [13]. The collective forest has long existing problems, such as poor forest quality and low productivity, which have seriously restricted forest resource growth and the sustainable development of forestry in China. Similar to other countries, property rights are the main obstacle to the development of collective forests in China [14].

Since China's reform and opening-up, the collective forest tenure regime has undergone several changes [15]. With the implementation of the Household Responsibility System 
in farmland, the collective forest tenure began a large-scale reform, that is, the forestry "Three-fixed" reform, in 1981. However, the property right of this reform was uncertain and changeable, and this resulted in the lack of management rights of households [16]. In such circumstances, households carried on the massive cutting to the collective forest to pursue short-term economic benefits $[17,18]$. In response, the government promptly stopped the distribution of collective forests; some areas have also recovered part of the allocated forestland [11]. In 2003, initiated by the Fujian, Jiangxi and Zhejiang provinces, a new round of collective forest tenure reform (CFTR) was launched to solve property rights. Additionally, this spread rapidly to other provinces in 2008. The CFTR is divided into the main reform and the supportive reform. The content of the main reform is to allocate forestland to households, and determine the farmers' rights to use, management forestland and ownership of the forest. The content of the supportive reform is much more complicated, including forest tenure mortgage loans, forestry insurance and the establishment and development of forestry cooperative organizations [15]. Through the reform, households have obtained the use right of the forestland and the ownership, management right and disposal right of the forest [19]. Improving the productivity of collective forests through the forest tenure reform is vital to the sustainable development of forest resources in China.

In practice, the CFTR has great differences in implementation, which causes the discordance range of forestland property rights among different regions [20]. Additionally, households still extensively manage forestland. Their enthusiasm for forestry production has not changed much, and the government has not achieved the goal of incentive households [21]. Theoretically, the effect of property rights on performance is exerted through human beings' actions [22]; that is, the forestland property rights held by households will influence the forest output through a certain path. Thus, does the current collective forest tenure regime affect forest resources? Additionally, how does this affect forest resources? All these questions need to be further verified.

Existing studies have not reached a consensus on land property rights' impact on forest resources. Some studies have shown that effective tenure arrangement is an important prerequisite for increasing forest output and contributing to forest resource growth [23,24]. Bray et al. [25] found that households' clear property rights in the Maya Forest region helped to improve the productivity of their forestlands. Simultaneously, unclear tenure is a major cause of deforestation and forest resource degradation [26,27]. De Oliveira [28] and Paneque-Gálvez et al. [29] analyzed the forestland tenure reforms in Brazil and Bolivia, respectively; they both found that stable forestland tenure would result in less deforestation and forest degradation. In contrast, Sikor [30] argued that the devolution of forestland property rights in Vietnam had little effect on the growth of forest area. Pacheco et al. [31] also pointed out that forest reforms in the Western Amazon have not addressed some critical constraints faced by smallholders in managing forests. The CFTR also encouraged households to invest various forestland factors by further clarifying collective forestland's rights, which was useful for increasing the forest stock of collective forests and promoting forestry production [32,33]. Zhang and Song [34] also pointed out that the rights granted to households by the CFTR were conducive to increasing the quantity and quality of forest resources. This is because the reform promoted forestry productivity and efficiency. While Liu et al. [35] found that the long-term performance of the CFTR has not yet been reflected, existing studies have not taken the multi-functional path of property rights affecting production into account. Likewise, households will make different decisions based on the growth cycles of different forest species [36]. It is necessary to select specific forest species to analyze the relationship between land property rights and forest resources.

The purpose of this paper is to analyze the mechanism and impact path of land property rights on forest resources. The rest of this paper is structured as follows: Section 2 presents the literature review. Section 3 shows the research methods, including model specification, data collection and variable selection. Section 4 reports the empirical results. Section 5 discusses its findings, and Section 6 concludes with policy implications. 


\section{Literature Review}

Absolute property rights mean they have exclusive access rights, free disposal rights and the exclusive profitable right [37]. The CFTR has granted more forestland rights to farmers, including clarifying the use right, ensuring profitable rights and implementing disposal rights [38]. Therefore, the use right, profitable right and disposal right constitute the complete forestland property rights. Indeed, with the deepening of the CFTR, forestry taxes and fees have been completely abolished, and there is no cutting quota on bamboo; farmers have exclusive profitable rights in bamboo production. However, due to the frequent adjustment of forestland property rights in the past, farmers have difficulty forming a stable cognition of forestland use rights. Meanwhile, the lag of supporting policies in the reform restricts farmers' autonomy in transferring or mortgaging their forestland. Thus, this paper focuses on forestland use and disposal rights, which mainly affect forestry production and management activities at the current stage.

Theoretically, property rights on performance depend on human behavior [22]. Specifically, security tenure clarifies the boundary of subjects' actions and promotes the subjects' behaviors. It functions as an incentive or constraint, the internalization of externalities and optimization of resource allocations to achieve the goal of improving performance [39,40]; that is, clarifying property rights will indirectly affect performance through investment incentives and resource allocation.

Generally, a clear definition of forestland property rights enables farmers to fully obtain the benefits from forestland investments without facing the risk of losing forestland's expected benefits [41]. It can internalize forestry production's externalities and increase farmers' enthusiasm to invest $[42,43]$. Due to the long-term production process of forests and its slow investment effect, the unclear definition of property rights will easily cause the partial income produced by forestland investment to turn into external income [44]; farmers are unable to ultimately obtain the income, so they will lose investment confidence and reduce forestland productivity. Since China's current forestry technology is not mature enough, forestland investment is still critical to improve forest output [45]. As a result, land property rights are likely to affect forest resources through forestland investment.

It is worth noting that the transaction cost of forestland is lower under the clear property right, which helps farmers enter the transaction market more conveniently and successfully trade forestland. This will promote the allocation of forestland resources to more efficient farmers to improve economic performance. However, currently, extensive management is still adopted in forestry production in China, and farmers reserve forestland through part-time management, which restricts forestland trade. This makes it difficult to achieve the goal of optimal allocation of forestland resources through the market transaction. Thus, we know that it is not practical that the current property right affects forest resource changes through the allocation of forestland in China.

Likewise, some studies have suggested that the change in land property rights would indirectly affect the agricultural production performance through labor allocation [46]. At present, China's rural social security system is not perfect; the stable and complete forestland use right ensures the social security function and the asset appreciation effect, indirectly reduces the opportunity cost of non-forest labor and restrains the allocation of the forestry labor force in rural households. The complete disposal right contributes to enhancing the trading of forestland and obtaining forestry production funds, which can restrain the allocation of forestry labor by releasing forestry labor [47]. As a result, the reallocation of the household labor force causes farmers to need to employ a labor force to ensure forestry production, which increases transaction costs and reduces forestry production efficiency because of insufficient supervision [48]. It can be seen that the allocation of the forestry labor force is also an intermediary variable of land property right, which affects forest resources.

In summary, the land property right mainly affects forest resources through the indirect effect of forestland investment and forestry labor force allocation. This paper 
chooses forestland investment and forestry labor allocation as intermediary variables to empirically examine the land property rights' impact on forest resources.

\section{Methods}

\subsection{Econometric Model Specification}

The change in forest resources in this paper is represented by the forest output, that is, the output per unit area of bamboo forest. As forest output is a continuous variable, we adopted the ordinary least square (OLS) model for regression. The specific model is as follows:

$$
Y_{i}=\gamma_{0}+\gamma_{i} X_{i}+\sigma
$$

where $Y_{i}$ is forest output, $X_{i}$ is the explanatory variable, $\gamma_{0}, \gamma_{i}$ are the parameters to be estimated and $\sigma$ is the residual.

As mentioned above, land property rights will affect forest output through forestland investment and forestry labor allocation. This paper further analyzes the intermediary role of forestland investment and forestry labor allocation. Refer to the method of Baron and Kenny [49]; the regression models are created as follows:

$$
\begin{gathered}
Y=c R+v_{1} \\
M=a R+v_{2} \\
Y=c^{\prime} R+b M+v_{3}
\end{gathered}
$$

where $Y$ represents forest output; $R$ stands for land property right (use right and disposal right); $M$ stands for intermediary variables (forestland investment and forestry labor allocation); and $v_{1}, v_{2}, v_{3}$ are residual terms. The coefficient $c$ of Equation (2) is the total effect of land property right $R$ on forest output $Y$. The coefficient $a$ of Equation (3) is the effect of land property right $R$ on intermediary variable $M$. The coefficient $b$ of Equation (4) is the effect of intermediary variable $M$ on forest output $Y$ after controlling the effect of land property right $R$. The coefficient $c^{\prime}$ is the direct effect of land property right $R$ on forest output $Y$ after controlling the effect of the intermediary variable. The Bootstrap method was used to test the intermediate effect.

In addition, when analyzing the impact of land property rights on the intermediary variables, the forestland investment is a continuous variable; we can continue to use the OLS model to estimate it. However, the forest labor allocation was measured by the proportion of the forestry labor force. As part of farmers' families did not participate in forestry production, the forest labor allocation is a restricted dependent variable. Therefore, we adopted the Tobit model to estimate the impact of land property rights on the forestry labor allocation. Here, the econometric models are specified as:

$$
\begin{aligned}
& Y_{i}^{*}=\beta_{0}+\sum_{i=1}^{n} \beta_{i} X_{i}+\mu_{i} \\
& Y_{i}=\left\{\begin{array}{c}
Y_{i}^{*}, \text { if } Y_{i}^{*}>0 \\
0, \text { if } Y_{i}^{*} \leq 0
\end{array}\right.
\end{aligned}
$$

where $Y_{i}^{*}$ is the unobservable latent variable; $Y_{i}$ represents the proportion of forestry labor force; $X_{i}$ is the explanatory variable; $\beta_{0}, \beta_{i}$ are the parameters to be estimated; and $\mu_{i}$ is the residual.

\subsection{Data Collection}

This study used data from bamboo plantation household surveys conducted in Zhejiang and Jiangxi provinces in 2017. Zhejiang and Jiangxi provinces are both rich in forest resources. The forest area of Zhejiang province is 6.6 million $\mathrm{hm}^{2}$, and its forest coverage is $61.2 \%$ [50]; the forest area of Jiangxi province in 2018 was 10.7 million $\mathrm{hm}^{2}$, and its forest coverage rate was $63.1 \%$ [51]. The CFTR selects these two provinces as pilot areas. Addition- 
ally, these selected pilot regions have significant differences in the economic development level, forestry development and forest tenure reform [52].

Anji and Suichang in Zhejiang province and Suichuan and Chongyi in Jiangxi province were chosen as research areas (as shown in Figure 1); these four forest-dependent counties were selected based on the bamboo resources and forest tenure reform, and because they are the critical priority forest counties and advanced counties that have promoted the CFTR in China [53]. Anji County is located in the northwest of Zhejiang province, with $70.2 \%$ forest cover in 2018 [54]; its bamboo stock and commercial bamboo are ranked first in the country. Take the bamboo industry as a leading industry; it is known in China as "Bamboo County". Suichang County lies in the southwest of Zhejiang province. With $83.4 \%$ forest cover in 2018 [55], it has great potential in the bamboo industry, and it is also the main bamboo production area for Zhejiang province. Suichuan County lies in Southwestern Jiangxi province, with $78.8 \%$ forest cover in 2018 [56]; bamboo is also among the pillar industries within it. Chongyi County lies in Southwestern Jiangxi. With $88.3 \%$ forest cover in 2018 [57], it has abundant forest resources, and was named the "Hometown of Bamboo in China".

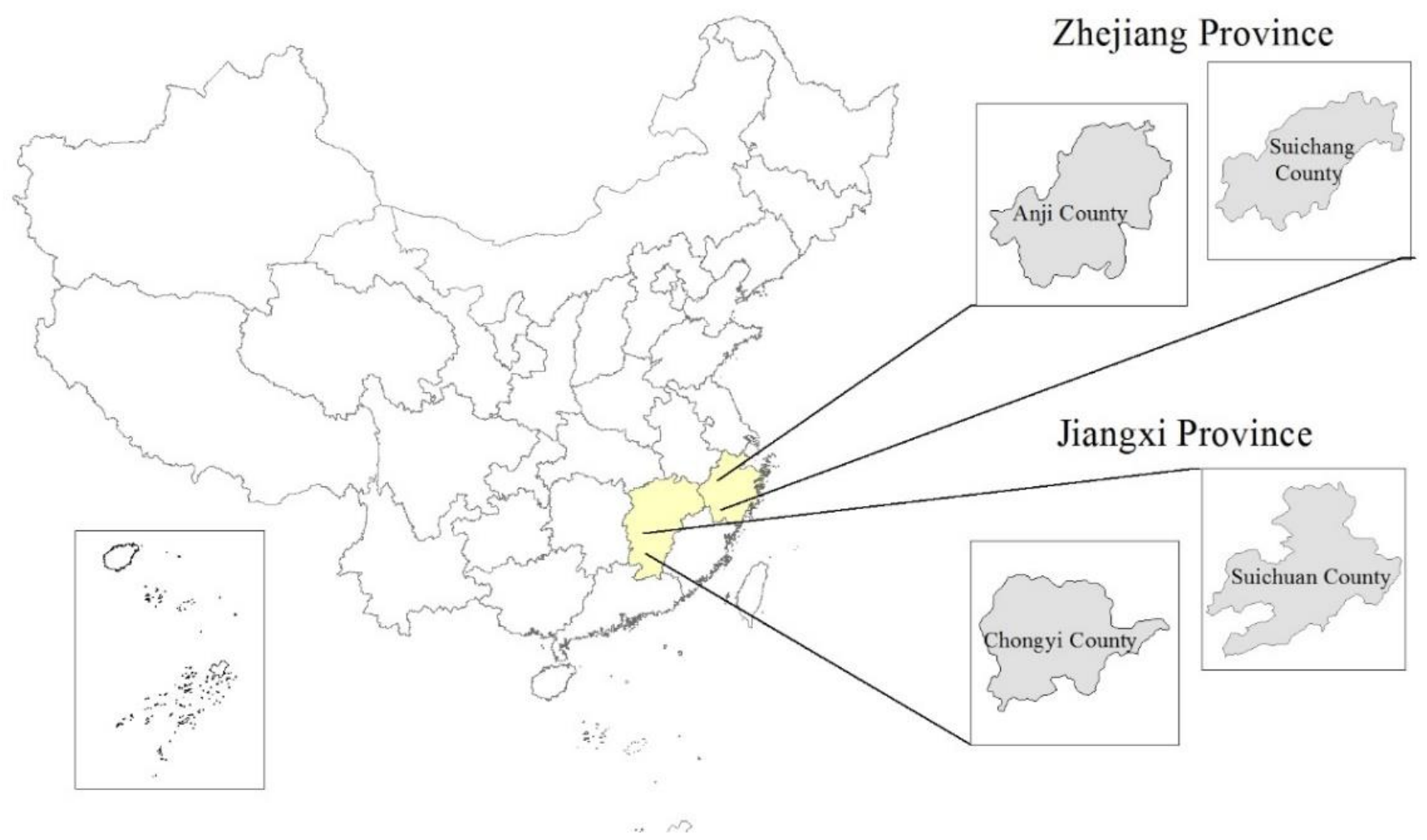

Figure 1. Geographical distribution of sample areas in Southern China.

According to the random sampling method, the research group first randomly selected three towns based on bamboo production in every investigation area, then randomly chose 3-4 administrative villages in each town. According to the investigation, some farmers in the sample area do not produce bamboo forests; we selected farmers who were involved in bamboo production and excluded the farmers who were not involved, and finally, we obtained 312 valid questionnaires.

\subsection{Variable Selection}

(1) Dependent variable. The dependent variable is forest resources, which are measured by forest output; forest output refers to the output of bamboo per unit area. According to the investigation, bamboo has high yield in some years, and a low yield in some other years, so we focus on bamboo's total production from 2015 to 2016. 
(2) Independent variables. This paper chose farmers' cognition of property rights to represent the land property right (including use right and disposal right). The use right is measured by the farmers' risk expectation of losing forestland in the future. If they are worried, then the value assigned is 1 ; if they are uncertain, then the value assigned is 2; and if they are not concerned, then the value assigned is 3 . The weighted average of the right to transfer the plot to other villagers, the right to transfer the plot to outsiders and the right to mortgage were used to represent the disposal right. For each right, if a farmer considers that he has the right, then the value assigned is 4 ; if the farmer considers that he has the right with the permission of the village or the forestry bureau, then the value assigned is 3; if farmer is uncertain, then the value assigned is 2 . If a farmer considers that he does not have the right, then the value assigned is 1 . In addition, we adopted the average understanding of rights of other farmers within the village to replace the level of farmer understanding of land property rights to avoid endogenity.

(3) Intermediate variables. Intermediate variables include forestland investment and forestry labor allocation. Forestland investment refers to the total input per unit area, including capital investment (such as the expenses of purchasing chemical fertilizer, pesticide and other production material, and the cost of transportation) and labor input (the sum of the discounting of home labor and the salary paid for hiring labor). Under the condition of the low level of forestland investment, forestland investment will promote the forest output. The proportion of forestry labor force measures the allocation of forestry labor force, that is, the proportion of forestry labor force to the total family labor force.

(4) Control variables. The control variables consist of four major characteristics: (a) household; (b) forestland; (c) village; (d) price; and (e) regional. The characteristics of farmer households include the age of the household head, the education of the household head, the off-farm experience of the household head and the household fixed assets. The age and the education of the household head reflect the basic situation of farmers' human capital. The off-farm experience of the household head shows the family relies less on forestry to make a living. The household fixed assets represent the family's economic condition. These household factors will affect farmers' forestry production and thus affect the forest output.

The forestland characteristics include the bamboo area, the bamboo plots and the bamboo plots' slope. A larger bamboo area can generate scale efficiency through large-scale operation and improve forest output. The number of bamboo plots indicates the fragmentation of forestland, and fragmented forestland will reduce its input-output efficiency. The bamboo plots' slope indicates the difficulty of bamboo production, and the higher slope of the bamboo plot is not conducive to improving forest output.

Village characteristics include the distance to the processing plant, the collaborative relationship between the village and processing plant, the proportion of bamboo area in the village and the distance to town. The distance to the processing plant and the collaborative relationship between the village and processing plant indicate the village's forestry market conditions. Whether the forestry market conditions are perfect has a direct impact on farmers' production enthusiasm, which in turn affects forest output. The high proportion of bamboo area in the village indicates that the bamboo forest resources in the village are relatively rich, and the production of bamboo forests can be increased by creating a good atmosphere. The farther the distance from the village to town, the lower the opportunity to engage in non-agricultural employment, and the higher the input into forestry production, which will help increase forest output.

The price characteristics refer to bamboo's market price, that is, the average price of bamboo in the village in the previous year. The higher the bamboo's market price, the greater the enthusiasm of farmers to manage bamboo, which helps to improve forest output. 
In addition, to control the influence of some unobservable regional features, this paper introduces a provincial dummy variable: Zhejiang. The variable definition and descriptive statistic are shown in Tables 1 and 2.

Table 1. Definitions of variables.

\begin{tabular}{|c|c|c|}
\hline & Variable Abb. & Definition \\
\hline Forest resources & Output & The output of bamboo per unit area $\left(\mathrm{kg} / \mathrm{hm}^{2}\right)$ \\
\hline \multirow{2}{*}{ Land property right } & Use & $\begin{array}{c}\text { Farmers' risk expectation of losing forestland in the future: } \text { worried }=1 \text {, } \\
\text { uncertain }=2, \text { not concerned }=3\end{array}$ \\
\hline & Disposal & $\begin{array}{l}\text { The weighted average of the right to transfer the plot to other villagers, the } \\
\text { right to transfer the plot to outsiders, and the right to mortgage }\end{array}$ \\
\hline \multirow{2}{*}{ Intermediate variables } & Investment & Total input per unit area (thousand yuan $/ \mathrm{hm}^{2}$ ) \\
\hline & Labor & Labor engagement in forestry production/total labor force \\
\hline \multirow{4}{*}{ Household characteristics } & Age & Age of household head (year) \\
\hline & Education & Education of the head of household (year) \\
\hline & Off-farm & Whether the household head has off-farm experience: Yes $=1, \mathrm{No}=0$ \\
\hline & Assets & Value of fixed assets (thousand yuan) \\
\hline \multirow{3}{*}{ Forestland characteristics } & Area & The actual area of bamboo production $\left(\mathrm{hm}^{2}\right)$ \\
\hline & Plots & The actual number of bamboo plots \\
\hline & Slope & The actual average slope of bamboo plots \\
\hline \multirow{4}{*}{ Village characteristics } & Plant & The distance from the village to the bamboo processing plant $(\mathrm{km})$ \\
\hline & Collaborative & $\begin{array}{c}\text { Whether the collaborative relationship between village and processing } \\
\text { plant is established: Yes }=1, \mathrm{No}=0\end{array}$ \\
\hline & Proportion & Bamboo area/ total forestland area in the village \\
\hline & Town & The distance from village to the nearest town $(\mathrm{km})$ \\
\hline Price characteristics & Price & The average price of bamboo in the village in the previous year (yuan/ $\mathrm{kg}$ ) \\
\hline Regional characteristics & Zhejiang & Zhejiang $=1$, others $=0$ \\
\hline
\end{tabular}

Table 2. Descriptive statistics.

\begin{tabular}{cccc}
\hline \multirow{2}{*}{ Forest resources } & Variable & Mean & Std. \\
\hline \multirow{2}{*}{ Land property right } & Output & $25,308.22$ & $46,979.10$ \\
& Use & 2.29 & 0.78 \\
& Disposal & 3.46 & 0.88 \\
\hline \multirow{2}{*}{ Intermediate variables } & Investment & 9.40 & 13.05 \\
& Labor & 0.33 & 0.36 \\
\hline \multirow{3}{*}{ Household characteristics } & Age & 59.22 & 10.38 \\
& Education & 6.35 & 3.52 \\
& Off-farm & 0.35 & 0.48 \\
& Assets & 523.90 & 486.20 \\
\hline \multirow{3}{*}{ Forestland characteristics } & Area & 1.95 & 3.42 \\
& Plots & 1.86 & 1.11 \\
& Slope & 50.22 & 13.24 \\
\hline \multirow{2}{*}{ Village characteristics } & Plant & 10.28 & 14.65 \\
& Collaborative & 0.09 & 0.29 \\
& Proportion & 0.58 & 0.29 \\
& Town & 5.24 & 3.71 \\
\hline Price characteristics & Price & 0.53 & 0.03 \\
\hline Regional characteristics & Zhejiang & 0.76 & 0.43 \\
\hline
\end{tabular}




\section{Results}

\subsection{Effect of Land Property Right on Forest Output}

Using Stata14.0 statistical software, this paper examined the multi-collinearity of all independent variables. The results show that the average expansion coefficient VIF of all the independent variables is 1.47 , which is much less than 10 . This means that there is no collinearity among the independent variables in the model. Therefore, the OLS model can be used to analyze the influencing factors of forest resources. The estimated results are shown in Table 3.

Table 3. Estimate results of land property right on forest output.

\begin{tabular}{|c|c|c|c|}
\hline \multirow{2}{*}{ Variable. } & \multicolumn{3}{|c|}{ Output } \\
\hline & Coefficient & Std. Err. & T Value \\
\hline \multicolumn{4}{|l|}{ Land property right } \\
\hline Use & 0.1912 & 0.134 & 1.38 \\
\hline Disposal & 0.1773 & 0.16 & 1.08 \\
\hline \multicolumn{4}{|c|}{ Intermediate variable } \\
\hline Investment $(\ln )$ & $0.4942 * * *$ & 0.05 & 9.79 \\
\hline Labor & $0.2693 * *$ & 0.11 & 2.51 \\
\hline \multicolumn{4}{|c|}{ Household characteristics } \\
\hline Age & -0.0033 & 0.00 & -0.81 \\
\hline Education & $-0.0297^{* * *}$ & 0.01 & -2.67 \\
\hline Off-farm & -0.0982 & 0.08 & -1.26 \\
\hline Assets (ln) & 0.0189 & 0.04 & 0.49 \\
\hline \multicolumn{4}{|c|}{ Forestland characteristics } \\
\hline Area $(\ln )$ & $-0.1110^{* *}$ & 0.04 & -2.49 \\
\hline Plots & -0.0521 & 0.04 & -1.46 \\
\hline Slope & -0.0028 & 0.00 & -1.01 \\
\hline \multicolumn{4}{|c|}{ Village characteristics } \\
\hline Plant $(\ln )$ & $0.0598^{* *}$ & 0.03 & 2.31 \\
\hline Collaborative & $-0.4437^{* * *}$ & 0.16 & -2.71 \\
\hline Proportion & $0.3931^{* * *}$ & 0.14 & 2.87 \\
\hline Town & 0.0018 & 0.01 & 0.17 \\
\hline \multicolumn{4}{|l|}{ Price characteristics } \\
\hline Price $(\ln )$ & 1.0594 & 0.75 & 1.41 \\
\hline \multicolumn{4}{|c|}{ Regional characteristics } \\
\hline Zhejiang & 0.0735 & 0.12 & 0.61 \\
\hline Con. & 0.4559 & 2.47 & 0.18 \\
\hline F value & & $23.52 * * *$ & \\
\hline$R^{2}$ & & 0.5763 & \\
\hline Number of obs & & 312 & \\
\hline
\end{tabular}

As shown in Table 3, in the land property right, the use right did not show significance in its effect on the forest output, nor did the disposal right, showing that the use right and the disposal right do not directly impact the forest output. Among the intermediary variables, the forestland investment showed significance at a $1 \%$ significance level regarding its effect on forest output. The coefficient was positive, indicating that forestland investment promoted forest output. The forestry labor allocation showed significance at a $5 \%$ significance level regarding its effect on forest output. The coefficient was positive, indicating that the higher the forestry labor force's proportion, the higher the forest output. With respect to control variables, the household head's education showed significance at a $5 \%$ significance level regarding its effect on forest output, and the coefficient was negative. The bamboo area showed significance at a $1 \%$ significance level in its impact on forest output with a negative coefficient. The distance to the processing plant showed significance 
at a $5 \%$ significance level concerning its effect on forest output with a positive coefficient. The collaborative relationship between village and processing plant showed significance at a $1 \%$ significance level concerning its effect on forest output with a negative coefficient. The proportion of bamboo area in the village showed significance at a $1 \%$ significance level in its impact on forest output, and the coefficient was positive.

\subsection{Intermediary Effect of Land Property Right on Forest Output}

\subsubsection{Effect of Land Property Right on Intermediary Variables}

As we can see from above, neither the right of use nor the disposal right has a significant direct impact on forest output. Still, the intermediary variables, such as forestland investment and forestry labor allocation, can significantly affect forest output. Therefore, to verify whether the use right or the disposal right has an indirect effect on forest output, we adopted the OLS model and the Tobit model to estimate whether the intermediary variables are affected by the land property right, and the regression results are shown in Table 4.

Table 4. Estimate results of land property rights on intermediary variables.

\begin{tabular}{|c|c|c|c|c|c|c|}
\hline \multirow{2}{*}{ Variable } & \multicolumn{3}{|c|}{ Investment (OLS) } & \multicolumn{3}{|c|}{ Labor (Tobit) } \\
\hline & Coefficient & Std. Err. & T Value & Coefficient & Std. Err. & T Value \\
\hline \multicolumn{7}{|l|}{ Land property right } \\
\hline Use & $0.3384 * *$ & 0.16 & 2.14 & -0.0573 & 0.12 & -0.48 \\
\hline Disposal & $0.4926^{* * *}$ & 0.19 & 2.66 & $-0.3604^{* * *}$ & 0.13 & -2.71 \\
\hline Control variables & & Yes & & & Yes & \\
\hline Con. & 3.5492 & 2.81 & 1.26 & 0.1536 & 0.74 & 0.21 \\
\hline F value & \multicolumn{3}{|c|}{$20.95^{* * *}$} & \multicolumn{3}{|c|}{$3.83^{* * *}$} \\
\hline $\mathrm{R}^{2}$ & \multicolumn{3}{|c|}{0.5150} & \multicolumn{3}{|c|}{-} \\
\hline Pseudo $\mathrm{R}^{2}$ & \multicolumn{3}{|c|}{-} & \multicolumn{3}{|c|}{0.1139} \\
\hline
\end{tabular}

Note: ${ }^{* * *}, * *$ and ${ }^{*}$ denote $1 \%, 5 \%$ and $10 \%$ significance levels, respectively.

In Table 4, the use right and the disposal right had a significant positive impact on forestland investment at the $5 \%$ and $1 \%$ significance level, respectively, and the coefficients were all positive. Regarding forestry labor allocation, the use right did not significantly affect it. However, the disposal right showed significance at a $1 \%$ significance level in its effect on forestry labor allocation with a negative coefficient. It can be concluded that forestland investment and forest labor allocation are the intermediary variables of land property rights affecting forest output.

\subsubsection{Intermediary Effect}

To prove whether the land property right affects the forest output through forestland investment and forestry labor allocation, this paper adopted the Baron and Kenny [49] method to examine the process of adding intermediary variables into the regression model step by step. By controlling the intermediary variables, we can see whether the land property right significantly affected forest output. The results are shown in Table 5.

Model 1 in Table 5 is the result of the regression model without intermediary variables; Models 2 and 3 are the result of a regression model with forestland investment and forestry labor allocation, respectively; Model 4 is the regression result of forestland investment and forestry labor force allocation. Comparing Model 1 with the others, we can find that, on the one hand, the coefficient of determination $\left(\mathrm{R}^{2}\right)$ of the model with intermediary variables is greater than that of Model 1, indicating that the explanatory and robustness were improved. On the other hand, the coefficients and significance of the use right and the disposal right are different. When introducing the forestland investment, the coefficients of the use right and the disposal right decreased, and its significance changed. When introducing the forestry labor allocation, the coefficients of the use right and disposal right increased; the 
significance of the use right did not change. In contrast, the significance of the disposal right increased.

Table 5. Regression results for the intermediary effect.

\begin{tabular}{|c|c|c|c|c|}
\hline Variable & Model 1 & Model 2 & Model 3 & Model 4 \\
\hline Use & $0.3501 * *(0.16)$ & $0.1817(0.14)$ & $0.3593 * *(0.16)$ & $0.1912(0.14)$ \\
\hline Disposal & $0.3597 *(0.19)$ & $0.1145(0.16)$ & $0.4273 * *(0.19)$ & $0.1773(0.16)$ \\
\hline Investment (ln) & - & $0.4977^{* * *}(0.05)$ & - & $0.4942 * *(0.05)$ \\
\hline Labor & - & - & $0.2980 * *(0.12)$ & $0.2693 * *(0.11)$ \\
\hline Control variables & Yes & Yes & Yes & Yes \\
\hline Con. & $2.9071(2.83)$ & $1.1407(2.47)$ & $2.1357(2.83)$ & $0.4559(2.47)$ \\
\hline F value & $14.71 * * *$ & $24.16^{* * *}$ & $14.38^{* * *}$ & $23.52 * * *$ \\
\hline $\mathrm{R}^{2}$ & 0.4271 & 0.5672 & 0.4382 & 0.5763 \\
\hline
\end{tabular}

Note: $(1)^{* * *}, * *$ and $*$ denote $1 \%, 5 \%$ and $10 \%$ significance levels, respectively. (2) Std. Err. are shown in the brackets.

\subsubsection{Direct and Indirect Effects of Land Property Right on Forest Output}

As mentioned above, land property rights affect forest output through two intermediary variables: forestland investment and forest labor allocation. Therefore, this paper further analyzed the direct and indirect effects of land property rights on forest output and examined the indirect effects (intermediary effect) of forestland investment and forestry labor allocation. This paper adopted the Bootstrap method to examine the intermediary effect; that is, using the Process program in SPSS software, through 5000 Bootstrap sampling analysis, the intermediary effects of forestland investment and forestry labor allocation were examined in $90 \%, 95 \%$ and $99 \%$ confidence intervals, respectively. By using the Bootstrap method, we examined the intermediary effect based on whether the confidence interval contains 0 value. If the confidence interval contains 0 value, the intermediary effect is not significant; if the confidence interval does not contain 0 value, the intermediary effect is significant. The results are shown in Tables 6-9.

The direct and indirect effects of the use right on forest output are shown in Table 6. The total effect of the use right on forest output is 0.3501 , showing significance at a $5 \%$ significance level (judged by $t$-test), and the coefficient is positive. The direct effect is 0.1912 , and the coefficient is positive, but it is not significant (judged by $t$-test). The indirect impact is 0.1589 , and the coefficient is also positive. Judging from the Bootstrap $90 \%, 95 \%$ and $99 \%$ confidence intervals, in the Bootstrap 90\% confidence intervals, the indirect effect of the use right does not contain 0 value, indicating that it is significant at a $10 \%$ significance level.

Table 6. Direct and indirect effects of forestland use right on forest output.

\begin{tabular}{ccccc}
\hline & Effect Value & Std. Err. & T Value & Bootstrap 90\% Confidence Intervals \\
\hline Total effect & $0.3501^{* *}$ & 0.16 & 2.20 & - \\
Direct effect & 0.1912 & 0.14 & 1.38 & - \\
Indirect effect & $0.1589^{*}$ & 0.09 & - & $(0.0115,0.3261)$ \\
\hline
\end{tabular}

Note: ${ }^{* *}$ and ${ }^{*}$ denote $5 \%$ and $10 \%$ significance levels, respectively.

Table 7 presents how the use right indirectly affects forest output through different paths. It can be seen that the indirect effects of two intermediary variables are different. Regarding forestland investment, the effect value is 0.1672 , showing significance at a $10 \%$ significance level (does not contain 0 value in the Bootstrap 90\% confidence intervals). Additionally, its coefficient is positive, which explains why the use right decreased when we examined the intermediary effect in Table 5. Concerning forest labor allocation, the effect value is -0.0083 , which is not significant, and the coefficient is negative. Compared with forest labor allocation, forestland investment contributes more, accounting for $105.22 \%$ of the indirect effect and $47.76 \%$ of the total effect. 
Table 7. Analysis of the indirect effect of use right on forest output.

\begin{tabular}{cccccc}
\hline Influence Path & Effect Value & Std. Err. & $\begin{array}{c}\text { Bootstrap 90\% } \\
\text { Confidence Intervals }\end{array}$ & $\begin{array}{c}\text { Indirect Effect } \\
\text { Ratio (\%) }\end{array}$ & $\begin{array}{c}\text { Total Effect } \\
\text { Ratio (\%) }\end{array}$ \\
\hline $\begin{array}{c}\text { Use } \rightarrow \text { Investment } \rightarrow \text { Output } \\
\text { Use } \rightarrow \text { Labor } \rightarrow \text { Output }\end{array}$ & $0.1672 *$ & 0.09 & $(0.0223,0.3298)$ & 105.22 & 47.76 \\
\hline
\end{tabular}

Note: * denote $10 \%$ significance level.

The direct and indirect effects of the disposal right on forest output are shown in Table 8. The total effect of disposal right on forest output is 0.3597 , showing significance at a $5 \%$ significance level, and the coefficient is positive. The direct effect is 0.1773 , and the coefficient is positive, but it is not significant. The indirect effect is 0.1824 , and the coefficient is positive, and it is significant at a $10 \%$ significance level (does not contain 0 value in the Bootstrap 90\% confidence intervals).

Table 8. Direct and indirect effects of forestland disposal right on forest output.

\begin{tabular}{ccccc}
\hline & Effect Value & Std. Err. & T Value & Bootstrap 90\% Confidence Intervals \\
\hline Total effect & $0.3597^{*}$ & 0.19 & 1.93 & - \\
Direct effect & 0.1773 & 0.16 & 1.08 & - \\
Indirect effect & $0.1824^{*}$ & 0.10 & - & $(0.0299,0.3684)$ \\
\hline
\end{tabular}

Note: * denote $10 \%$ significance level.

Table 9 presents how the disposal right indirectly affects forest output through a different path. Regarding forestland investment, the effect value is 0.2435 , and it does not contain 0 value in the Bootstrap 99\% confidence intervals, showing significance at a $1 \%$ significance level. Additionally, the coefficient is positive. Concerning forest labor allocation, the effect value is -0.0611 , showing significance at a $1 \%$ significance level and the coefficient was negative. This shows that the disposal right has a significant positive effect on forest output through forestland investment, and a significant adverse effect on household forest output through forestry labor allocation. Thus, we can explain why the disposal right's coefficient decreased when we introduced forestland investment, and the coefficient of the disposal right increased when we introduced forestry labor allocation to examine the intermediary effect. Although the two paths play opposite roles, compared with forestry labor allocation, the forestland investment contributes more, accounting for $133.50 \%$ of the indirect effect and $67.70 \%$ of the total effect.

Table 9. Analysis of the indirect effect of disposal right on forest output.

\begin{tabular}{|c|c|c|c|c|c|}
\hline Influence Path & Effect Value & Std. Err. & $\begin{array}{c}\text { Bootstrap } 99 \% \\
\text { Confidence Intervals }\end{array}$ & $\begin{array}{c}\text { Indirect Effect } \\
\text { Ratio (\%) }\end{array}$ & $\begin{array}{c}\text { Total Effect } \\
\text { Ratio (\%) }\end{array}$ \\
\hline Disposal $\rightarrow$ Investment $\rightarrow$ Output & $0.2435 * * *$ & 0.10 & $(0.0302,0.5393)$ & 133.50 & 67.70 \\
\hline Disposal $\rightarrow$ Labor $\rightarrow$ Output & $-0.0611^{* * *}$ & 0.03 & $(-0.1809,-0.0035)$ & -33.50 & -16.99 \\
\hline
\end{tabular}

Note: ${ }^{* * *}$ denote $1 \%$ significance level.

\section{Discussion}

In line with earlier research $[28,29]$, the results of our study indicate that property rights are a key factor affecting forest resources. However, the most significant extension of this study upon previous studies is the analysis of the different pathways of property rights affecting forest output. In considering forestland investment and forestry labor allocation, this paper finds that property rights do not significantly affect forest output. However, both forestland investment and forestry labor allocation have an impact on forest output. The reason for this is that, on the one hand, the higher the investment, the faster the bamboo growth, the higher the bamboo quality and the higher the bamboo output per unit area. On the other hand, forestry labor allocation improved the level of bamboo resources, and increased the bamboo output. Simultaneously, we find that the use right 
and the disposal right will increase forestland investment, which is in line with the studies by Ji et al. [20] and Ren et al. [58]. While our results further find that the disposal right has a restraining impact on forestry labor allocation, based on this, an unexpected finding is that land property rights can indirectly affect forest output through forestland investment and forestry labor allocation.

Compared to the existing literature [34], our results reflect the extent of the intermediary role of forestland investment and forestry labor allocation in the process of land property rights affecting forest output. The findings indicate that the use right plays a crucial role in forest output through forestland investment. A possible explanation for this is that with the improved use right, farmers' risk of losing forestland in the future is reduced; the probability of gaining profit for farmers is increased; and farmers' motivation and confidence to invest in forestland are enhanced, which leads to higher forest output [59] On one hand, the forestland can be transferred or mortgaged, encouraging farmers to invest. On the other hand, farmers can be released from forestland and engage in off-farm activities. However, with the characteristics of low-frequency labor investment, forestland can be managed part-time or by employing workers for rural households, resulting in labor allocation that is ineffective [60].

Our study also finds that the higher the household head's education, the lower the forest output. This might be because the farmers with higher education preferred to engage in off-farm activities than forestland production. The bamboo area significantly and negatively affected forest output. A possible reason for this is that farmers with a larger bamboo area may cut bamboo in a different growth stage. Another interesting finding is that the farther the distance from the village to the processing plant, the higher the forest output. One possible explanation for this is that when the village is far from the processing plant, concerning the higher transaction cost and difficulties in selling, farmers may cut more bamboo during a harvest period to reduce the transaction cost. We find that the collaborative relationship between the village and processing plant has a significant negative effect on forest output. This might be because the collaborative ties have enabled a fixed path to the sale of bamboo and reduced the selling difficulty for farmers; farmers would cut some high-quality bamboo for sale in a short harvest period. Additionally, the results indicate that the more extensive the proportion of bamboo area, the higher the forest output. This might be because the abundant bamboo resources contribute to forming a competitive market and encouraging farmers to promote forest output.

\section{Conclusions}

Using survey data of bamboo planters in Zhejiang and Jiangxi provinces, this paper analyzed the effect of land property rights on forest resources. Particular interest was focused on the pathway of land property rights affecting forest output. We adopted the OLS model to estimate the impact of land property rights on forest output, and also estimated the OLS model and Tobit model to explore the effect of land property rights on intermediary variables. Moreover, the Bootstrap method was used to examine the intermediary effect. The empirical results show that the forestland use right and disposal right do not have a statistically significant direct effect on forest output. In spite of this, the indirect effect of both the use right and disposal right on forest output is statistically significant; that is, the property rights can affect forest output by influencing the relevant forestry behaviors of farmers.

Furthermore, the results also reveal that the improved use right has a significant positive effect on forest output through encouraging farmers to invest. However, the impact of the use right through forestry labor allocation is not statistically supported. In relation to the disposal right, it imposes a positive effect on forest output through forestland investment, whereas it negatively affects forest output by allocating forestry labor. Although this negative coefficient is small, it is still significant at the $1 \%$ level. Eventually, we find that the overall effect of disposal right on forest output is positive and significant, which depends on the intensities of these two opposite effects. 
The findings of our study have important policy implications for future policy making in the forestland tenure management in China. On one hand, since the output of forest resources is influenced by the improved and stable forestland property rights, policy makers should focus on improving the law and actual tenure security, strengthening farmers' awareness of property rights and increasing farmers' enthusiasm for forestland investment. On the other hand, while ensuring the labor input in forestry, policies should further optimize the allocation of surplus labor and promote the transfer of surplus labor.

While this study represents most of the collective forest areas in Southern China, we should be cautious to extend the results to the whole region. Moreover, as the forestry ownership worldwide has primarily transformed from industrial forestry to small-scale forestry, the decentralization of forestland property rights has been the trend of forest management in most countries, especially in developing countries. The experience of China's forestland tenure reform may not be directly transferred to others, but we anticipate that the same policy attributes that improve the integrity and stability of property rights to effectively stimulate households to produce and increase forest output would be important considerations when effectively managing decentralized forests elsewhere in the world. Therefore, such studies would provide some concrete evidence for forestry development in other countries.

Author Contributions: Y.Y. conceived and designed this study and wrote the introduction and literature reviews. Y.N. wrote the methods, performed the analysis and discussed the results. H.L. gave suggestions on the entire writing process and reviewed all the sections. L.C. gave suggestions and revised the manuscript. All authors have read and agreed to the published version of the manuscript.

Funding: This research was supported by the Fundamental Research Funds of CAF (grant no. CAFYBB2019MB001), the Humanities and Social Sciences Research Foundation of Education Department in Shaanxi Province (grant no. 20JT062) and the Humanities and Social Sciences Research Foundation of Education Department in Shaanxi Province (grant no. 20JZ090).

Data Availability Statement: The data presented in this study are available on request from the corresponding author. As it comes from field surveys conducted by the research team, the data are not publicly available.

Conflicts of Interest: The authors declare no conflict of interest.

\section{References}

1. Agrawal, A.; Chhatre, A.; Hardin, R. Changing governance of the world's forests. Science 2008, 320, 1460-1462. [CrossRef] [PubMed]

2. Chen, J.; Innes, J.L. The implications of new forest tenure reforms and forestry property markets for sustainable forest management and forest certification in China. J. Environ. Manag. 2013, 129, 206-215. [CrossRef] [PubMed]

3. Sikor, T.; Baggio, J. Can smallholders engage in tree plantations? An entitlements analysis from Vietnam. World Dev. 2014, 64, S101-S112. [CrossRef]

4. Coleman, E.A. Institutional factors affecting biophysical outcomes in forest management. J. Policy Anal. Manag. 2010, 28, 122-146. [CrossRef]

5. Liscow, Z.D. Do property rights promote investment but cause deforestation? Quasi-experimental evidence from Nicaragua. J. Environ. Econ. Manag. 2013, 65, 241-261. [CrossRef]

6. Liu, C.; Liu, H.; Wang, S. Has China's new round of collective forest reforms caused an increase in the use of productive forest inputs? Land Use Policy 2017, 64, 492-510. [CrossRef]

7. White, A.; Martin, A. Who Owns the World's Forests? Forest Trends: Washington, WA, USA, 2002.

8. Jagger, P.; Luckert, M.K.; Duchelle, A.E.; Lund, J.F.; Sunderlin, W.D. Tenure and forest income: Observations from a global study on forests and poverty. World Dev. 2014, 64, 43-55. [CrossRef]

9. Zhang, Y.; Zhang, D.; Schelhas, J. Small-scale non-industrial private forest ownership in the United States: Rational and Implications for forest management. Silva Fenn. 2005, 39, 443-454. [CrossRef]

10. Luckert, M.K.; Haley, D.; Hoberg, G. Policies for Sustainably Managing Canada's Forests: Tenure, Stumpage Fees, and Forest Practices; UBC Press: Vancouver, BC, Canada, 2012.

11. Siikamäki, J.; Ji, Y.; Xu, J. Post-reform forestland markets in China. Land Econ. 2015, 91, 211-234. [CrossRef]

12. State Forestry and Grassland Administration of China (SFGA). China Forest Resource Report (2014-2018); China Forestry Press: Beijing, China, 2019. 
13. Liu, C. The Decentralization of Collective Forestland Tenure Reform in China Since the Reform and Opening-up from the Perspective of Evolutionary Game Theory. China's Rural Econ. 2020, 5, 21-38. (In Chinese)

14. Qin, P.; Carlsson, F.; Xu, J. Forest tenure reform in China: A choice experiment on farmers' property rights preferences. Land Econ. 2011, 87, 473-487. [CrossRef]

15. Zhang, H.; Kuuluvainen, J.; Ning, Y.; Liao, W.; Liu, C. Institutional Regime, Off-Farm Employment, and the Interaction Effect: What are the Determinants of Households' Forestland Transfer in China? Sustainability 2017, 9, 1885. [CrossRef]

16. Zhang, T.T.; Yao, S.B.; Yu, J.N.; Hatab, A.A.; Liu, Z. Effects of China's Collective Forestland Tenure Reform Policies on Forest Product Firm Values. Land 2020, 9, 127. [CrossRef]

17. Liu, D. Tenure and Management of Non-State Forests in China since 1950: A Historical Review. Environ. Hist. $2001,6,239-263$.

18. Démurger, S.; Yang, W. Economic changes and afforestation incentives in rural China. Environ. Dev. Econ. 2006, 11, 629-649. [CrossRef]

19. Zhang, H.; Kuuluvainen, J.; Yang, H.; Xie, Y.; Liu, C. The Effect of Off-Farm Employment on Forestland Transfers in China: A Simultaneous-Equation Tobit Model Estimation. Sustainability 2017, 9, 1645. [CrossRef]

20. Ji, D.; Ma, X.; Shi, X. The Impact of Forest Property Rights on Forestland Investments: From the Perspective of Property Rights Integrity and Security-a Case from Suichuan and Fengcheng of Jiangxi Province. Agric. Econ. Issues 2015, 3, 54-61. (In Chinese)

21. Liu, C.; Wang, S.; Liu, H. An examination of the effects of recent tenure reforms in China's collective forests on peasants' forest activities and their income. Int. For. Rev. 2017, 19, 55-67. [CrossRef]

22. Luo, B.L.; Gao, L. Reform of the Collective Forest Tenure System-Guangdong's Practice and Model Innovation; China Agriculture Press: Beijing, China, 2013. (In Chinese)

23. Nelson, G.C.; Harris, V.; Stone, S.W. Deforestation, land use, and property rights: Empirical evidence from Darien, Panama. Land Econ. 2001, 77, 187-205. [CrossRef]

24. Berkes, F.; Colding, J.; Folke, C. Navigating Social-Ecological Systems: Building Resilience for Complexity and Change; Cambridge University Press: Cambridge, UK, 2003.

25. Bray, D.B.; Duran, E.; Ramos, V.H.; Mas, J.F.; Velazquez, A.; McNab, R.B.; Barry, D.; Radachowsky, J. Tropical deforestation, community forests, and protected areas in the Maya Forest. Ecol. Soc. 2008, 13, 56. [CrossRef]

26. Johann, E. Climate Change: Financing Global Forests; Office of Climate Change: London, UK, 2008.

27. Chomitz, K.M.; Buys, P.; Luca, G.D.; Thomas, T.S.; Wertz-Kanounnikoff, S. At Loggerheads? Agricultural Expansion, Poverty Reduction, and Environment in the Tropical Forests; World Bank Publications: Washington, DC, USA, 2007.

28. De Oliveira, J.A.P. Property rights, land conflicts and deforestation in the Eastern Amazon. For. Policy Econ. 2008, 10, 303-315 [CrossRef]

29. Paneque-Gálvez, J.; Mas, J.F.; Gueze, M.; Luz, A.C.; Macía, M.J.; Orta-Martinez, M.; Pino, J.; Reyes-García, V. Land tenure and forest cover change. The case of southwestern Beni, Bolivian Amazon, 1986-2009. Appl. Geogr. 2013, 43, 113-126. [CrossRef]

30. Sikor, T. The allocation of forestry land in Vietnam: Did it cause the expansion of forests in the northwest? For. Policy Econ. 2001, 2, 1-11. [CrossRef]

31. Pacheco, P.; Mejía, E.; Cano, W.; de Jong, W. Smallholder forestry in the western Amazon: Outcomes from forest reforms and emerging policy perspectives. Forests 2016, 7, 193. [CrossRef]

32. Shen, Y.; Zhang, Y.; Xu, X.; Zhu, Z.; Jiang, C. Towards decentralization and privatization of China's collective forestlands: A study of nine villages in 3 provinces. Int. For. Rev. 2009, 11, 28-35. [CrossRef]

33. Holden, S.T.; Xu, J.; Jiang, X. Tenure security and investment effects of forest tenure reform in China. In Land Tenure Reform in Asia and Africa: Assessing Impacts on Poverty and Natural Resource Management; Holden, S.T., Otsuka, K., Deininger, K., Eds.; Macmillan: New York, NY, USA, 2013; pp. 256-282.

34. Zhang, Y.; Song, W.M. Study on the impact of forest tenure system reform on forest resources in collective forest areas. J. Agrotech. Econ. 2012, 4, 96-104. (In Chinese)

35. Liu, C.; Wang, S.; Liu, H.; Zhu, W. Why did the 1980s' reform of collective forestland tenure in southern China fail? For. Policy Econ. 2017, 83, 131-141. [CrossRef]

36. Qin, P.; Xu, J. Forest land rights, tenure types, and farmers' investment incentives in China: An empirical study of Fujian Province. China Agric. Econ. Rev. 2013, 5, 154-170. [CrossRef]

37. Cheung, S.N.S. The structure of a contract and the theory of a non-exclusive resource. J. Law Econ. 1970, 13, 49-70.

38. Xie, L.; Berck, P.; Xu, J. The effect on forestation of the collective forest tenure reform in China. China Econ. Rev. 2016, 38, 116-129. [CrossRef]

39. Broegaard, R.J. Land tenure insecurity and inequality in Nicaragua. Dev. Chang. 2005, 36, 845-864. [CrossRef]

40. Chen, Z.; Qu, F. The Structure of Farmland Property Rights and Agricultural Performance: A Theoretical Framework. Acad. Mon. 2006, 9, 87-92. (In Chinese)

41. Mullan, K.; Grosjean, P.; Kontoleon, A. Land tenure arrangements and rural-urban migration in China. World Dev. 2011, 39, 123-133. [CrossRef]

42. Brasselle, A.S.; Gaspart, F.; Platteau, J.P. Land tenure security and investment incentives: Puzzling evidence from Burkina Faso. J. Dev. Econ. 2002, 67, 373-418. [CrossRef]

43. Deininger, K.; Jin, S. Tenure security and land-related investment: Evidence from Ethiopia. Eur. Econ. Rev. 2006, 50, 1245-1277. [CrossRef] 
44. Jacoby, H.G.; Li, G.; Rozelle, S. Hazards of expropriation: Tenure insecurity and investment in rural china. Am. Econ. Rev. 2002, 92, 1420-1447. [CrossRef]

45. Ma, X.L. Impact of Farmland Tenure Security on Agricultural Performance: A Case Study on Investment-incentive Effect and Resource-allocation Effect of Three Villages in Hilly Areas. J. Nanjing Agric. Univ. 2010, 10, 72-79. (In Chinese)

46. Ma, X.L. Does Tenure Security Matter? Rural Household Responses to Land Tenure Reforms in Northwest China; Wageningen University: Wageningen, The Netherlands, 2013.

47. Valsecchi, M. Land Property Rights and International Migration: Evidence from Mexico; Working Papers in Economics; University of Gothenburg: Gothenburg, Sweden, 2012.

48. Feng, S.; Heerink, N.; Ruben, R.; Qu, F. Land rental market, off-farm employment and agricultural production in southeast China: A plot-level case study. China Econ. Rev. 2010, 21, 598-606. [CrossRef]

49. Baron, R.M.; Kenny, D.A. The moderator-mediator variable distinction in social psychological research: Conceptual, strategic, and statistical considerations. J. Pers. Soc. Psychol. 1986, 51, 1173-2282. [CrossRef]

50. Zhejiang Forestry Bureau. Available online: http:/ / www.zjly.gov.cn/col/col1275946/index.html (accessed on 20 December 2020).

51. The People's Government Jiangxi. 2018 Bulletin on Land Greening in Jiangxi Province. Available online: http:/ / www.jiangxi.gov. cn/art/2019/3/12/art_396_665576.html (accessed on 26 December 2020).

52. Yang, Y.; Li, H.; Liu, Z.; Hatab, A.A.; Ha, J. Effect of Forestland Tenure Security on Rural Household Forest Management and Protection in Rural China. Glob. Ecol. Conserv. 2020, 22, e00952. [CrossRef]

53. Yang, Y.; Li, H.; Liu, Z.; Cheng, L.; Abu Hatab, A.; Lan, J. Effect of forestland property rights and village off-farm environment on off-farm employment in Southern China. Sustainability 2020, 12, 2605. [CrossRef]

54. Anji County Bureau of Statistics of China. Anji Investigation Team of National Bureau of Statistics of China (ACBSC). Anji Statistical Yearbook; China Statistics Press: Beijing, China, 2018.

55. Lishui Municipal People's Government of China (LMPGC). Various Data of Forest Resources in Suichang County Are among the Top in the Province. 2018. Available online: http://www.lishui.gov.cn/zfzx/tpxx/201910/t20191012_4147227.html (accessed on 5 January 2021).

56. Suichuan County People's Government of China (SCPGC). Overview of Suichuan County. 2018. Available online: http:/ /www suichuan.gov.cn/doc/2019/06/10/36577.shtml (accessed on 11 January 2021).

57. Chongyi County Bureau of Statistics of China; Chongyi County People's Government of China (CCBSC). Statistical Communique of National Economic and Social Development of Chongyi County in 2018. 2018. Available online: http:/ /www.chongyi.gov.cn/ xxgk/tjxx/201904/t20190401_996998.html (accessed on 8 February 2021).

58. Ren, Y.; Kuuluvainen, J.; Yang, L.; Yao, S.B.; Xue, C.X.; Toppinen, A. Property Rights, Village Political System, and Forestry Investment: Evidence from China's Collective Forest Tenure Reform. Forests 2018, 9, 541. [CrossRef]

59. Yi, Y.; Köhlin, G.; Xu, J. Property rights, tenure security and forest investment incentives: Evidence from China's Collective Forest Tenure Reform. Environ. Dev. Econ. 2014, 19, 48-73. [CrossRef]

60. Zhu, X.J.; Zhang, H.X.; He, W.J. Forest property reform, property rights structure and farmers' forestland transfer decision. Inst. Econ. Res. 2014, 4, 170-187. (In Chinese) 